\title{
Records Management: A Case Study in Business Office of Universitas Klabat
}

\author{
Rouna Paoki \\ Akademi Sekretari Manajemen Indonesia Klabat
}

\begin{abstract}
The purpose of this research was to identify the records management and to determine the challenges in records management at the business office of Universitas Klabat. This case study utilized five employees from the business office of Universitas Klabat. The data collection techniques used were observation and interview using Miles and Hubberman model. The observation showed that the business office has applied the filing system; however, the staff lacked the skills in manipulating the filing system. Therefore, the filing system was not in accordance to the correct filing standards. This study implied that each employee needs more knowledge in records management. Aside from the employees, it is recommended that the office secretaries participate in records management training. Further, the records facilities should be improved to support the records management in the offices. Lastly, a clear procedure in records management should be developed and implemented.
\end{abstract}

Keywords: management, records 